\title{
Research concerning the Ball Screen in Basketball
}

\author{
Dan Ionescu 1
}

\begin{abstract}
The dynamics of basketball, due to the relatively small court but also to regulations concerning the time of attack, has required finding, by the specialists in this field, new ways of collaboration and specific actions between a certain team's players. Thus has appeared the 2 on 2 play, with its improved version called pick and roll, which has "exploded" over the last years, becoming the most important element in many coaches' strategy. As a description, pick and roll represents the tactic move to which participate the player in possession of the ball and a tall player, which screen him out, temporarily blocking the way of its defender. The purpose of this research is analyzing, in a national champion team, the frequency, the versions and the efficiency of these tactic moves.
\end{abstract}

Key words: basketball, pick and roll, frequency, efficiency

\section{Rezumat}

Dinamica jocului de baschet, datorată terenului relativ redus dar și prevederilor regulamentare privind timpul de atac, a solicitat din partea specialiștilor domeniului găsirea de noi mijloace de colaborare și acțiuni specifice între jucătorii unei echipe. Astfel a apărut jocul de 2 la 2, cu varianta sa îmbunătățită numită pick and roll, care a „explodat” în ultimii ani ajungând cel mai important element din strategia multor antrenori. Ca descriere, pick and roll reprezintă acțiunea tactică la care iau parte jucătorul aflat în posesia mingii și un jucător înalt, care-I face blocaj, barând temporar drumul de deplasare al apărătorului acestuia. Scopul acestui studiu este de a analiza frecvența, variantele și eficiența acestei acțiuni tactice la o echipă campioană natională.

Cuvinte cheie: baschet, pick and roll, frecvență, eficiență

\footnotetext{
${ }^{1}$ Assist. PhD, ”Politehnica" University Timișoara, Romania, e-mail: dan.ionescu@upt.ro
} 


\section{Hypothesis and purpose}

Starting from the hypothesis that ball screen is an important element in the game strategy [1], we have set as purpose pursuing and inventorying this collective action, using specific techniques and methods.

The purpose of this research has been to determine in what measure the players of the studied team have managed to apply the ball screen [2], which have been the most used versions and especially the efficiency of this action.

\section{Methods and subjects}

The theoretical documentation has contained explaining, based on specialized literature, terms related to ball screen and the versions of thisoffensive move - pick and roll [3], pick and pop [4], and pick and slide [5].

Also, in order to accomplish the purposes of this research, I have used the analytical method of video data processing.

In the season of 2012-2013, the national championship for teams in under-23 category, has counted four teams and has had place in five tournaments, each team playing a total of 15 games. Here is the ranking at the end of the season: 1. BCM Danzio Timișoara; 2. University of Cluj Napoca; 3. Olimpia Bucharest; 4. SCMU Craiova.
The subjects of research have been the members of the girls basketball team BCM Danzio Timișoara, national champion at under-23 category, having as coaches Dan Ionescu and Veronica Gavrilă.

\section{Results}

The analysis was focused on finding the number of ball screen's of the total number of attacks, the court areas in which these screen's have taken place compared with the midcourt line, with the three-point line, as well as with the free throw line. The analysis was also focused on the percentage of the success in this offensive move, the results obtained being contained in tables:

Table 1 shows that, out of 1242 attacks, the studied team has tried to take advantage of the advantages of ball screen 343 times, which represents $27.61 \%$. Also, the percentage of the court areas from which the studied team has tried to initiate and capitalize ball screen is specified. The central area of the court (the area delimited by the imaginary prolongation of the sidelines of the three second area) has been used the most for the execution of a pick and roll move - 162 times, representing $47.23 \%$ out of the total moves. The left area of the court has been used 116 times - 33.81\%, while the right area of the offensive side has been used 65 times, representing $18.95 \%$ out of the total moves.

Table 1. Percentage of moves and court areas where they have taken place

\begin{tabular}{|c|c|c|c|c|c|c|c|c|}
\hline \multirow{2}{*}{$\begin{array}{c}\text { Opposing } \\
\text { team }\end{array}$} & \multirow{2}{*}{$\begin{array}{l}\text { No. of Ball } \\
\text { screen's }\end{array}$} & \multicolumn{3}{|c|}{$\begin{array}{c}\text { Court area in which the ball screen } \\
\text { has been initiated }\end{array}$} & \multicolumn{2}{|c|}{$\begin{array}{l}\text { Place of ball screen } \\
\text { compared with the } \\
\text { three-point line }\end{array}$} & \multicolumn{2}{|c|}{$\begin{array}{c}\text { Place of ball screen } \\
\text { compared with the free- } \\
\text { throw line }\end{array}$} \\
\hline & & Left & Center & Right & $\begin{array}{l}\text { Inside the } \\
\text { line }\end{array}$ & $\begin{array}{l}\text { At/outside } \\
\text { the line }\end{array}$ & $\begin{array}{l}\text { Above the } \\
\text { line }\end{array}$ & $\begin{array}{l}\text { Under the } \\
\text { line }\end{array}$ \\
\hline $\begin{array}{l}\text { University of } \\
\text { Cluj Napoca } \\
\mathbf{3 5 7}\end{array}$ & $\begin{array}{c}132 \\
(36.97 \%)\end{array}$ & $\begin{array}{c}\mathbf{5 0} \\
(37.87 \%)\end{array}$ & $\begin{array}{c}62 \\
(46.96 \%)\end{array}$ & $\begin{array}{c}20 \\
(15.15 \%)\end{array}$ & $\begin{array}{c}27 \\
(20.45 \%)\end{array}$ & $\begin{array}{c}105 \\
(79.54 \%)\end{array}$ & $\begin{array}{c}120 \\
(90.90 \%)\end{array}$ & $\begin{array}{c}12 \\
(9.09 \%)\end{array}$ \\
\hline $\begin{array}{c}\text { Olimpia } \\
\text { Bucharest } \\
\mathbf{4 3 1}\end{array}$ & $\begin{array}{c}117 \\
(27.14 \%)\end{array}$ & $\begin{array}{c}41 \\
(35.04 \%)\end{array}$ & $\begin{array}{c}\mathbf{5 3} \\
(45.29 \%)\end{array}$ & $\begin{array}{c}23 \\
(19.65 \%)\end{array}$ & $\begin{array}{c}28 \\
(23.93 \%)\end{array}$ & $\begin{array}{c}89 \\
(76.06 \%)\end{array}$ & $\begin{array}{c}104 \\
(88.88 \%)\end{array}$ & $\begin{array}{c}13 \\
(11.11 \%)\end{array}$ \\
\hline $\begin{array}{l}\text { SCMU } \\
\text { Craiova } \\
\mathbf{4 5 4}\end{array}$ & $\begin{array}{c}94 \\
(20.70 \%)\end{array}$ & $\begin{array}{c}25 \\
(26.59 \%)\end{array}$ & $\begin{array}{c}47 \\
(50 \%)\end{array}$ & $\begin{array}{c}22 \\
(23.40 \%)\end{array}$ & $\begin{array}{c}28 \\
(29.78 \%)\end{array}$ & $\begin{array}{c}66 \\
(70.21 \%)\end{array}$ & $\begin{array}{c}\mathbf{8 1} \\
(86.17 \%)\end{array}$ & $\begin{array}{c}13 \\
(13.82 \%)\end{array}$ \\
\hline $\begin{array}{l}\text { TOTAL } \\
1242\end{array}$ & $\begin{array}{c}343 \\
(27.61 \%)\end{array}$ & $\begin{array}{c}116 \\
(33.81 \%)\end{array}$ & $\begin{array}{c}162 \\
(47.23 \%)\end{array}$ & $\begin{array}{c}\mathbf{6 5} \\
(18.95 \%)\end{array}$ & $\begin{array}{c}83 \\
(24.19 \%)\end{array}$ & $\begin{array}{c}260 \\
(75.80 \%)\end{array}$ & $\begin{array}{c}305 \\
(88.92 \%)\end{array}$ & $\begin{array}{c}38 \\
(11.07 \%)\end{array}$ \\
\hline
\end{tabular}


We can thus draw one first conclusion, namely that the central area of the court offers more opportunities to finalize the attack. After using the screen and after obtaining a mini-advantage created by the switch between players, the player with the ball could go towards the basket, pass decisively to the player who has come to box out for him and then he could demarcate straight to the basket, or the first player could pass to a demarcated teammate, situated on each of the sidelines of the court [6].

Depending on the team structure in the court, on the chosen possibilities of finalization (two or three point throw) and on the reaction of the opposing team against the ball screen, the team of BCM Danzio has realized over $75 \%$ of the blocks outside or at the three-point line (260 times). Equally disproportioned has been the situation concerning the area in which the block out has been realized, compared with the free-throw line, with 305 $(88.92 \%)$ cases above this line.

The data contained in table 2 show that the most used version for ball screen has been the pick and roll one (192 times, representing 55.97\%). Pick and pop version has been used 114 times (33.23\%), the last one being pick and slide, used only 37 times (10.78\%).

Table 3 shows the percentage of the successful actions of ball screen, depending on the areas in which they have been used. By successful action we mean getting a foul, scoring a basket or scoring a basket with foul.

Table 2. Percentage of the used ball screen versions

\begin{tabular}{ccccc}
\hline \multirow{2}{*}{ Opposing team } & $\begin{array}{c}\text { Total number of ball } \\
\text { screen's } \\
\text { (average/game) }\end{array}$ & Pick and Roll & Pick and Pop & Pick and Slip \\
\cline { 3 - 5 } $\begin{array}{c}\text { University of } \\
\text { Cluj Napoca }\end{array}$ & $\mathbf{1 3 2}$ & $\mathbf{7 6}$ & $\mathbf{4 8}$ & $\mathbf{8}$ \\
Olimpia & $(26.4)$ & $(57.57 \%)$ & $(36.36 \%)$ & $(6.06 \%)$ \\
Bucharest & $\mathbf{1 1 7}$ & $\mathbf{6 4}$ & $\mathbf{3 4}$ & $\mathbf{1 9}$ \\
SCMU & $(23.4)$ & $(54.70 \%)$ & $(29.05 \%)$ & $(16.23 \%)$ \\
Craiova & $\mathbf{9 4}$ & $\mathbf{5 2}$ & $\mathbf{3 2}$ & $\mathbf{1 0}$ \\
& $(18.8)$ & $(55.31 \%)$ & $(34.04 \%)$ & $(10.63 \%)$ \\
\hline TOTAL & $\mathbf{3 4 3}$ & $\mathbf{1 9 2}$ & $\mathbf{1 1 4}$ & $\mathbf{3 7}$ \\
\hline
\end{tabular}

Table 3. Percentage of the successful actions depending on the court area in which they have been used

\begin{tabular}{|c|c|c|c|c|c|c|c|c|c|}
\hline \multirow{3}{*}{$\begin{array}{l}\text { Opposing } \\
\text { team }\end{array}$} & \multicolumn{3}{|c|}{ Left side area } & \multicolumn{3}{|c|}{ Central area } & \multicolumn{3}{|c|}{ Right side area } \\
\hline & \multirow{2}{*}{$\begin{array}{c}\text { Total no. } \\
\text { of ball } \\
\text { screen's }\end{array}$} & \multicolumn{2}{|c|}{$\begin{array}{c}\text { Finalization of the } \\
\text { action }\end{array}$} & \multirow{2}{*}{$\begin{array}{l}\text { Total no. } \\
\text { of ball } \\
\text { screen's }\end{array}$} & \multicolumn{2}{|c|}{$\begin{array}{c}\text { Finalization of the } \\
\text { action }\end{array}$} & \multirow{2}{*}{$\begin{array}{l}\text { Total } \\
\text { no. of } \\
\text { ball } \\
\text { screen's }\end{array}$} & \multicolumn{2}{|c|}{$\begin{array}{l}\text { Finalization of the } \\
\text { action }\end{array}$} \\
\hline & & $\begin{array}{l}\text { In favor } \\
\text { of the } \\
\text { attack }\end{array}$ & $\begin{array}{c}\text { In favor } \\
\text { of } \\
\text { defense }\end{array}$ & & $\begin{array}{c}\text { In favor } \\
\text { of the } \\
\text { attack }\end{array}$ & $\begin{array}{c}\text { In favor } \\
\text { of } \\
\text { defense }\end{array}$ & & $\begin{array}{l}\text { In favor } \\
\text { of the } \\
\text { attack }\end{array}$ & $\begin{array}{c}\text { In favor } \\
\text { of } \\
\text { defense }\end{array}$ \\
\hline $\begin{array}{l}\text { University } \\
\text { of } \\
\text { Cluj Napoca }\end{array}$ & 50 & $\begin{array}{c}\mathbf{2 8} \\
(56 \%)\end{array}$ & $\begin{array}{c}22 \\
(44 \%)\end{array}$ & 62 & $\begin{array}{c}39 \\
(62.90 \%)\end{array}$ & $\begin{array}{c}23 \\
(37.09 \%)\end{array}$ & 20 & $\begin{array}{c}7 \\
(35 \%)\end{array}$ & $\begin{array}{c}13 \\
(65 \%)\end{array}$ \\
\hline $\begin{array}{l}\text { Olimpia } \\
\text { Bucharest }\end{array}$ & 41 & $\begin{array}{c}25 \\
(60.97 \%)\end{array}$ & $\begin{array}{c}16 \\
(39.02 \%)\end{array}$ & 53 & $\begin{array}{c}35 \\
(66.03 \%)\end{array}$ & $\begin{array}{c}18 \\
(33.96 \%)\end{array}$ & 23 & $\begin{array}{c}12 \\
(52.17 \%)\end{array}$ & $\begin{array}{c}11 \\
(47.82 \%)\end{array}$ \\
\hline $\begin{array}{l}\text { SCMU } \\
\text { Craiova }\end{array}$ & 25 & $\begin{array}{c}18 \\
(72 \%)\end{array}$ & $\begin{array}{c}7 \\
(28 \%)\end{array}$ & 47 & $\begin{array}{c}33 \\
(70.21 \%)\end{array}$ & $\begin{array}{c}14 \\
(29.78 \%)\end{array}$ & 22 & $\begin{array}{c}13 \\
(59.09 \%)\end{array}$ & $\begin{array}{c}9 \\
(40.90 \%)\end{array}$ \\
\hline TOTAL & 116 & $\begin{array}{c}71 \\
(61.20 \%) \\
\end{array}$ & $\begin{array}{c}\mathbf{4 5} \\
(38.79 \%) \\
\end{array}$ & 162 & $\begin{array}{c}107 \\
(66.04 \%) \\
\end{array}$ & $\begin{array}{c}\mathbf{5 5} \\
(33.95 \%) \\
\end{array}$ & 65 & $\begin{array}{c}32 \\
(49.23 \%) \\
\end{array}$ & $\begin{array}{c}33 \\
(50.76 \%) \\
\end{array}$ \\
\hline
\end{tabular}


The central area of the court has brought most satisfactions, 107 actions (66.04\%) out of the total 162 ending in favor of the attack. The big number of successful actions may also represent the reason why this area of the court has been most used for ball screen.

Not far from this value were situated the actions initiated in the left area of the court. Thus, 71 out of 116 actions, representing $61.20 \%$, ended in favor of the attack. One explanation could be that the player in possession of the ball, due to the block out received from a teammate, was able to go towards the basket, dribbling with his right hand.

The actions initiated in the right area of the court were situated at the other extreme, with successful actions of only $49.23 \%$ in favor of the attack. A possible explanation could be the need of going towards the basket by dribbling with the left hand.

Overall, we could say that the players of the studied team have been well organized concerning the versions of ball screen, managing to capitalize 210 (61.22\%) out of a total of 343 attacks used (graphic no.1)

Graph 1. Finalization of the action

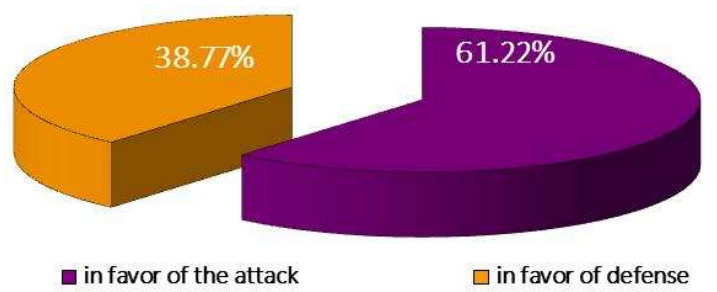

\section{Discussions}

Following the analysis of the offensive move pick and roll we cannot ignore the fact that the successful actions of this type of attack are determined by the quality of the participating players. By quality we mean the level of technical and tactical knowledge and of psychomotric skills, as well as the somatic type [7]. In the studied team there was only one center player whose motricity specific to the basketball game was able to partially satisfy the application of this king of attack. During the time when this player was not in the court, the actions based on pick and roll [8] did not suffer, but have also been efficiently realized by the players which didn't have the same somatic characteristics.

\section{Conclusions}

- At the studied team, the ball screens are important elements in the game strategy, over $27 \%$ of the total number of attacks being based on this action.

- At the studied team, the percentage of successful actions using pick and roll has had a fluctuating value, depending on the area in which the action has had place.

- When the number of the opponents and the level of the defense increase, the number of successful actions decreases.

- The percentage of using offensive moves pick and roll and of its versions (pick and pop and pick and slide), has generally had an almost constant value, no matter the opponent or its type of defense.

- The difference between the extreme performances (the amplitude) is of $16.81 \%$. This fact brings to coaches the issue of emphasizing the factors which determine the efficiency of pick and roll, in order to decrease its fluctuation from a preparatory stage to another.

\section{References}

1. Negulescu C. (2004) Caracteristici si tendinte in continutul sistructura jocului de baschet competitional de mare performantă.A.N.E.F.S., Bucuresti;

2. Ionescu D. (2003) Baschet. Curs de bază, Editura Augusta, Timisoara, p. 126;

3. Krause J. (Editor) Meyer, D. Meyer J. (2006) Kosarkaske vezbe\& vestine, Barex \& Barley Books, Beograd, p. 40;

4. Obradovic Z. (2007) Panathinaikos Offense, FIBA Assist Magazine no. 26, p. 24;

5. Jansen J.W. (2007) Pick and roll. Offense, Defense and a planfor youth development, Netherlands Basketball Federation, p. 15 ;

6. Karalejic M., Ahmetovic Z., Jakovljevic S., Novovic M. (1998) Kosarka - Prirucnik za trenere, Kosrakaski Savez Srbije, Beograd,p. 267

7. Colibaba-Evulet D., Bota I. (1998) Jocuri sportive. Teorie simetodică, Editura Aldin, Bucuresti, p. 36;

8. Cenic B. (2002) Kosarka. Tehnika i taktika, Visa Kosarkaska Skola, Beograd, p. 147. 